\title{
INNOVATION
}

\section{Recording volatiles arrested in tissues and body fluids as a tool to reveal crimes against women}

\section{Choudhary P, Verma KL, Chandela R \& Varghese LT}

Regional Forensic Science Laboratory, Government of National Capital Territory of Delhi, Yashwant place, Chanakyapuri, New Delhi, India.

\section{ABSTRACT}

Background: Women were symbolized as goddess Shakti (Power) but with modernization our value devastated and now women are objectified on the basis of sexuality. In modern era crime against women including female infanticide, feticide, child- marriage, sexual harassment, rape, kidnapping, threats, intimidation, stalking, cyber stalking, pornography, verbal abuse, physical abuse, prostitution, trafficking, dowry related violence etc. are increasing with time globally. The lack of education, disturbed-patriarchal mindset, loopholes in law and order, low conviction rate are few reasons that give rise to crimes like these and affects lives of millions of women. The main aim of the study is addressing the challenges of detection of major constituent of house hold floor cleaner and cosmetics in biological matrices. The authors have undertaken forensic examination of cases where household substances have been used in violence against women and have observed that detection of such chemical is very challenging. Accordingly, in this paper we have reported two cases emphasizing crimes against women, one case of persistent stalking which leads to suicide and another case of domestic violence related to dowry where in there was an attempt to murder. In both the cases different household volatile substance were used to commit crime.

Methodology: Qualitative and quantitative analyses of substances were carried out by using latest techniques including Gas chromatography - Mass spectroscopy (GC-MS), Headspace-Gas chromatography - Mass spectroscopy (HS-GC-MS).

Results: Alpha-pinene, 3-carene,o-cymene, d-limonene, eucalyptol, gamma-terpinene, ethanol, toluene, p-xylene, fenchone, fenchol, camphene, isoborneol, acetone and methyl alcohol were main compounds which were found during analysis in various forensic exhibits of different cases examined.

Conclusion: With the above mentioned hyphenated chromatographic techniques, various toxic volatiles can be analyzed without the need for additional methods.

Keywords: Crime against women, Gas chromatography - Mass spectroscopy (GC-MS), Head-space-Gas chromatography - Mass spectroscopy (HS-GC-MS), Forensic Science

Corresponding Author: Choudhary P pallavi.choudhary23@gmail.com ORCID iD: https://orcid.org/0000-0002-3246-3048

Article History

Received: 13.07 .2020

Received in revised form: 31.12 .2020

Accepted: 13.01.2021

Available online: 20.05 .2021

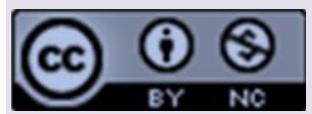

This article is licensed under the terms of the Creative Commons Attribution-Non Commercial 4.0 International License.

\section{BACKGROUND}

Indian culture began with the Vedic era. India Carries a chronological record of women being worshipped as goddess that is quite evident in the Holy Scriptures penned down during ancient times. However, her place in society deteriorated in the course of time ${ }^{12}$. Changes faced by modern civilization in political, social and economic aspects ${ }^{1}$ could be a reason for the degradation of the condition of women in society and increased rate of crime against women such as female infanticide, feticide, molestation, humiliation, eve-teasing, 
sexual harassment, rape, kidnapping, vitriolage, intimidation, stalking, cyber stalking, pornography, verbal, physical and economic abuse, domestic violence, prostitution, trafficking, dowry related violence $^{3},{ }^{4,5}$. The report of the national crime record bureau of India states that 378,277 cases related to crimes against women were reported in 2018 while in 2017 there were 359,849 incidences were reported under this category. The crime rate was 58.8 per 100,000 women in 2018 although in 2017 and 2016 it was 57.9 and 55.5 respectively. According to the National Crime Records Bureau (NCRB) 2018, cruelty by the husband or his relatives was the most common crime against women (31.9\%) followed by assault on women with intent to outrage her modesty (27.6\%), kidnapping and abduction $(22.5 \%)$ and rape $(10 \%)^{6}$. There is a crime of violence recorded against women in India 1.7 minute, a woman is raped every 16 minutes and a woman encounters domestic violence every $4.4 \mathrm{~min}^{7}{ }^{7}$ The annual crime in India report as published by NCRB after two years delay shows there are $3,59,849$ cases of crime against women reported in country ${ }^{8}$.

The brutal rape and torture committed on 16 December 2012 on a young 23-year-old medical aspirant ${ }^{9}$, created a ripple in the public throughout the nation resulting in Criminal Law (Amendment) Act, 2013 in Indian Penal Codes (IPC). It gave an extensive meaning to rape that was not restricted to sexual intercourse only (Sec. 375 IPC), and also introduced new offences like acid attack (326 A), attempted acid attack (326 B), Sexual Harassment and acting with intent to disrobe women ( $354 \mathrm{~A}$, 354 B), Voyeurism $\left(354\right.$ C) and Stalking (354 D) ${ }^{10}$. Although rape law was amended violence against women did not reduce. Multiple rapes, gang rapes and molestation are being committed by repeat offenders and keep jolting the country. ${ }^{11-19}$ The audacity of these criminals is such that they blame the victims for the event ${ }^{20}$. The Unnao Rape Case (U.P.), of 2019 which concerned sexual assault and live burning of a Hyderabad's Veteran (Cyberabad) $^{21,22}$ is serious. Globally $35 \%$ of women have experienced violence with figures as high as $70 \%$ in some countries where they experience abuse and torture of various dimensions. Calls to helplines increased more than 5 times during the covid-19 pandemic which is an indicator of increasing vulnerability of women across the globe. 144 countries have passed laws on domestic violence and 154 countries have laws on sexual harassment. However, data reveals that violence against women has increased significantly in recent years ${ }^{23}$

Volatile compounds (eucalyptol, gamma-terpinene, fenchone, fenchol, camphene, isoborneol) and organic solvents (Ethanol, Methanol, Chloroform, Acetone etc.) that are easily available in households and workplaces or can be brought from a market without a prescription, are widely used in women trafficking, forced sex, bondage, abduction, dowry deaths, date rapes / gang rapes, or for suicide by women suffering trauma ${ }^{24-26}$.

The conviction rate i.e. $50 \%$ in 2018 for India with Japan at leading $99.9 \%{ }^{27}$. This depicts the lack of scientific approach towards evidence at crime scene and old and classical laboratory analysis procedures that needs to be upgraded. The fast response of the scene of crime team, the proper collection and preservation of the exhibits and the submission of the exhibits to the forensic science laboratory at the earliest, is indispensable for scientific examination and submission of a report in a structured timeframe to the investigating agencies in order to assist the justice system.

The main objective of this manuscript is to emphasise the detection of volatiles (nail polish remover and floor cleaners) used in crimes against women by modern instrumental techniques like GCMS and HS-GC-MS and to discuss aspects of qualitative identification and intricacies involved in interpretation of result.

\section{Case 1}

A 21 year old married woman was admitted to hospital by her family with an alleged history of ingestion of an unknown substance. The remnants of the gastric lavage and a plastic bottle with liquid contents were submitted for forensic examination. The individuals life was saved following gastric lavage. Further investigation revealed that the relationship of victim with her in laws was not harmonious and she was frequently abused emotionally and physically for her inability to bear a child.

\section{Case 2}

A 17 year old girl was admitted to hospital by her family in an unconscious state with a history of ingestion of about $100 \mathrm{ml}$ of nail polish remover at home. She died during the course of treatment. Investigation revealed that the girl was being stalked and that she may have committed suicide due to this. A post-mortem examination revealed $100 \mathrm{ml}$ whitish liquid in the stomach with yellow discoloration of the stomach wall. Lung, Liver, spleen and kidney were congested. The lower lobe of both lungs revealed multiple consolidations. 
On sectioning froth mixed blood oozed out of Viscera (Stomach and its contents, piece of small intestine, liver, kidney and spleen). Femoral blood was preserved for toxicological examination and submitted.

\section{METHODOLOGY}

Reagent and apparatus: Anhydrous Ammonium sulphate, acetic acid, ammonia, Sodium tungstate, Diethyl ether, Chloroform, hydrochloric acid $(\mathrm{HCl})$ analytical grade(AR) from Merck. Equipment used included Reference ${ }^{\circledR}$ pipettes with disposable tips (Borosil, India), Hamilton Microlab ${ }^{\circledR 503 A}$ diluter/dispenser with 1-mL reagent syringe, $100 \mu \mathrm{L}$ sample syringe (Hamilton, Reno NV) \& manual crimper (Agilent), Elga, Flex 2 water purifier and all glassware used were from Borosil.

Biological exhibits (viscera, blood and gastric lavage fluid) were screened using alkaline, acidic and neutral ether extraction, as detailed below. The nonbiological exhibits (liquid contents submitted in plastic bottles) were distilled and examined as detailed below. Thin layer chromatography (TLC) was carried out to rule out presence of pesticides and suspected drugs ${ }^{28}$. Qualitative analysis of volatile poisons after distillation was undertaken using hyphenated chromatographic techniques. The details are described below.

Extraction procedure $^{28}: 50 \mathrm{~g}$ of macerated visceral tissues (stomach, intestine, liver, kidney and spleen) were treated with $10 \mathrm{~g}$ of anhydrous ammonium sulphate and $10 \mathrm{ml}$ of acetic acid, then subjected to digestion on a water bath for 3 hours at $100{ }^{\circ} \mathrm{C}$ and further screened using alkaline, acidic and neutral ether extraction ${ }^{28} .1 \mathrm{ml}$ of blood was diluted with deionized water, treated with a pinch of sodium tungstate and $2 \mathrm{ml}$ of concentrated Hydrochloric acid. The deproteinized blood was extracted and analyzed by TLC.

Distillation procedure: $5 \mathrm{~g}$ of visceral tissue added to a conical flask then $5 \mathrm{ml}$ of dilute Hydrochloric acid was added into it and set over the distillation apparatus. For analysis of phenolic compounds distillate was collected in $10 \mathrm{ml}$ of $1 \mathrm{~N}$ sodium hydroxide solution in volumetric flask in ice cooled condition and for other volatiles compound distillate was collected in volumetric flask without sodium hydroxide. Blood and gastric lavage fluid were also distilled by the same procedure. The blank control was also subjected in the all chemical test to rule out any contamination. Nail polish removers and floor cleaners of various brands sold in Delhi, India, purchased from local market were examined for confirmation and comparison.

Thin layer Chromatography (TLC): For these 2 case studies preliminary examination of samples was done using TLC plates (silica gel G 60 F254) activated at $105^{\circ} \mathrm{C}$ for $30 \mathrm{~min}$. The chamber was saturated for $30 \mathrm{~min}$. The solvent system used for TLC was: Chloroform/Acetone (8:2) and Chloroform/Methanol (9:1). The developed plates were sprayed with suitable reagents to visualize the location of drugs and pesticides ${ }^{28}$. The tests were negative for all the exhibits when screened for drugs and pesticides (data not shown).

Gas Chromatography-Mass Spectroscopy: Agilent 7890B GC with Mass Detector 5977A was used to analyze all the exhibits. The setting of the instrument is as described: Column- HP-5MS(30M $\mathrm{x}$ $0.250 \mathrm{~mm} \times 0.25 \mu$ ) Oven Temperature-initially $100{ }^{\circ} \mathrm{C}$ for $1.5 \mathrm{~min}$ then rate of $7^{\circ} \mathrm{C} / \mathrm{min}$ till $300{ }^{\circ} \mathrm{C}$ for 10 min, Injection Temperature $-280^{\circ} \mathrm{C}$, Injection volume - $1 \mu \mathrm{L}$, Mode - Split, Carrier Gas - Helium, Flow Rate - $70.9 \mathrm{ML} / \mathrm{min}$., MSD parameters included EI tune type, temperature of $\mathrm{MS}$ source - $300^{\circ} \mathrm{C}$, temperature of MS Quad- $150^{\circ} \mathrm{C}$, Start Mass- 29.00 End Mass-400. Total run time for a cycle was $25 \mathrm{~min}$. Mass spectral library:- National Institute of Standards and Technology (NIST), NIST MS 2.2 mass spectral library

\section{Headspace-Gas Chromatography-Mass} Spectrophotometry: HSGC-FID/MS method : An Agilent gas chromatograph coupled with Head Space Sampler, FID and Mass Selective Detector (Agilent Technologies, Wilmington, Delaware, USA) was used for the assay in HS-GC-FID/MS configuration consisting of a GC (Agilent 7890B) equipped with a FID and MS detector (MSD 5977A) coupled to an Agilent (7697A) HS sampler. The Dean's Switch was configured using a 1:1 split ratio to the FID and MS according to the manufacturer's instructions using fused-silica capillary restrictors with dimensions of $1.06 \mathrm{~m} \times 0.18 \mathrm{~mm}$ to the FID and $2.89 \mathrm{~m} \times 0.18 \mathrm{~mm}$ to the MS. Helium was used as the carrier gas. Separation of analytes by gas chromatography was carried out using a J \& W DB-5MS (column 1) capillary column ( $5 \%$ phenylmethylpolysiloxane, $30 \mathrm{~m}$ $\times 0.25 \mathrm{~mm} \times 0.25 \mu \mathrm{m}$, Agilent). Ionization was accomplished by electron impact (EI) and the MSD operated under selected ion monitoring (SIM) mode. The Headspace parameters (HS) was as follows: the oven maintained at $70{ }^{\circ} \mathrm{C}$, the loop was maintained at $85^{\circ} \mathrm{C}$ and the transfer line was maintained at 130 ${ }^{\circ} \mathrm{C}$. Before injection of the sample, the vials were incubated for $15 \mathrm{~min}$ at $70^{\circ} \mathrm{C}$. The injection time was held constant at $1 \mathrm{~min}$. The injection port was 
maintained at $150{ }^{\circ} \mathrm{C}$ and operated in split mode with split ratio of 30:1, maintaining a pressure of 9.7 psi, septum purge flow of $5 \mathrm{ml} / \mathrm{min}$. The chromatographic gradient (GC) was programmed as follows: an initial oven temperature of $40{ }^{\circ} \mathrm{C}$ was held for $6 \mathrm{~min}$ and then increased in a linear fashion to $220^{\circ} \mathrm{C}$ at $20^{\circ} \mathrm{C} / \mathrm{min}$. At the end of each run, the initial temperature was reset to the initial condition. Helium carrier gas (with purity $99.999 \%$ ), was set to $0.6 \mathrm{~mL} / \mathrm{min}$ flow rate (column 1) and flow rate for column 2 and 3 were 3.98 and $1.60 \mathrm{~mL} / \mathrm{min}$ respectively. The FID detector was held at $250{ }^{\circ} \mathrm{C}$. The gas flow rates were as follows hydrogen 40.0 $\mathrm{mL} / \mathrm{min}$, air $400.0 \mathrm{~mL} / \mathrm{min}$ and nitrogen 20.0 $\mathrm{mL} / \mathrm{min}$. The nitrogen flow rate was maintained at a constant 15 psi. The GC run time was 15 min. MSD temperature was at $300{ }^{\circ} \mathrm{C}$ and MS Quadrupole was maintained at $150{ }^{\circ} \mathrm{C}$, the ionization energy in mass was $70 \mathrm{eV}$ and was scanned from 29 to $400 \mathrm{amu}$ at a rate of 3.0 scans/s. Total run time for HSGC is 30 minutes per sample. To maximize sensitivity, the MSD was auto-tuned by using fluorotributylamine (PFTBA, tuning standard). Ionization of the analytes by electron impact (EI) was obtained using an emission current of $70 \mathrm{eV}$. GC/MS Mass Hunter with MSD Chem Station Data Analysis software (Version B.07.00) was used for data analysis and quantitation.

\section{Sample preparation for Instrumental analysis and quantification of Ethanol and Methanol:}

$1 \mathrm{ml}$ of sample (calibrators, controls, and case samples) was mixed with $90 \mu \mathrm{l}$ of $\mathrm{n}$-propanol (internal standard) of concentration $21.7 \mathrm{mg} / \mathrm{dl}$ and placed in a $20-\mathrm{mL}$ headspace vial with the Hamilton Microlab ${ }^{\circledR}$ 503A diluter/dispenser, crimped and sealed. Quantitation was performed using the response ratio of the FID response of ethanol to $n$ propanol. One set of positive and negative controls was analyzed prior to case samples and one set immediately after case samples. A five point calibration curve was used to determine the concentration of ethanol and methanol in blood samples. The range of concentration levels for the ethanol $7.9 \mathrm{mg} / \mathrm{dl}$ to $39.5 \mathrm{mg} / \mathrm{dl}$ and methanol 15.8 $\mathrm{mg} / \mathrm{dl}$ to $79 \mathrm{mg} / \mathrm{dl}$. Calibration curves were constructed by plotting the mean response ratio (response of analyte/response of $n$ - propanol used as internal standard) against the mean amount ratio (amount of analyte/amount of internal standard) (Figure 1). Ethanol was identified by retention times and target qualifier ions. The calibration curves were linear $R(2) \geq 0.996)$. Limit of detections and limit of quantifications were calculated on the basis of signal to noise ratio.

\section{RESULT}

\section{CASE 1}

alpha-pinene, 3-carene,o-cymene, D-limonene, eucalyptol and gamma-terpinene compounds were detected in gastric lavage fluid of the deceased. Along with these compounds, ethanol, toluene, $\mathrm{p}$-xylene, fenchone, fenchol, camphene and isoborneol were detected in bottle which was found at crime scene (Table1, Figure 2A, 2B, \& 2C). For preliminary examination, distillate was subjected to various chemical tests. Distillate showed presence of ethanol. A market formulation of floor cleaner was also run to compare with case exhibits. (Figure 2D)

\section{CASE 2}

Methanol and acetone were detected in viscera and blood. Ethanol was found only in viscera sample of the deceased. For preliminary examination, distillate was subjected to chemical tests. Distillate showed positive reaction with Legal' test ${ }^{28}$, Schiff's reagent test $^{28}$ and potassium dichromate test ${ }^{28}$. For this case various brand of floor cleaners were used for comparison. Quantification of methanol was done in blood of deceased through GC-HS. The chromatogram produced clearly indicates the presence of ethanol at retention time (Rt) 3.954 minute, methanol at 3.736 minute. Methanol level in the blood was quantified as $40 \mathrm{mg} / 100 \mathrm{ml}$ of blood $\mathrm{n}$ - propanol used as an internal standard elutes at Rt 4.16 minute which is indicative of the fact that our method is well in place. The positive chemical test gave the lead to move for confirmatory test of the target poison through complimentary techniques of GC-HS and HS- GC-MS (Table 1 \& Figure $3 \mathrm{~A}, \& 3 \mathrm{~B})$.

\section{DISCUSSION}

In case study 1 floor cleaners purchased from the local market were also analyzed by the instrument and results were compared with the gastric lavage and extract from the bottle. Presence of similar components in all samples suggest use of floor cleaner to commit the crime. Literature survey reveals that lethal ingestion of house hold cleaner can be fatal and characterization of biogenic volatile organic compounds emiting from cleaning products has been successfully detected by GC-MS in biological specimens as well as packaged containers $^{29,30,31}$. In case study 2, nail polish removers of different brands were compared with extracts of viscera and blood of the victim. Presence of ethanol, acetone and methanol in exhibits as well 
as in the market formulations suggest use of nail paint remover to commit suicide. The use of volatiles compound in these two cases showed administration of mixtures containing volatile compounds in violence against women. Criminal use of chloroform and methanol is mentioned in the literature ${ }^{32,33}$. Comprehensive toxicological examination including instrumental analysis of viscera and body fluids gives a clear picture about the possibility of unknown compounds which may otherwise escape during routine screening with the toxicologist missing the target compound.

\section{CONCLUSION}

Crimes against women are commonly encountered in the Indian subcontinent where it is a societal problem. For a forensic toxicologist, detection of volatiles and associated constituents is difficult if samples are not adequately preserved. The cases examined indicates that HS-GC-MS is suitable for rapid qualitative analysis for unknown volatile components with miniscule sample preparation. This technique is extremely successful especially where a history of ingestion of household cleaning agents which are thermally sensitive volatile compounds are suspected. The development and application of techniques for headspace collection of volatiles in combination with GC-MS gives credibility to the chemical examination of challenging forensic exhibits. Our findings demonstrated that body tissues and human blood is a good source of volatile organic compounds (VOCs) and relevant target for toxicological screening of signature VOCs in forensic specimens specially when the cases are related to household chemical and cosmetics using hyphenated techniques (HS-GC-MS). This has provide an incredible opportunity for the detection of substance earlier believe to be challenging. There is further scope for investigation through spectroscopic techniques such as Gas chromatography - Infra red spectroscopy (GC-IR) depending upon the forensic science laboratory which has access to such alternative techniques. Quick and contamination free separation with low solvent consumption minimizes the exposure of toxicologist to hazardous chemicals and reduces the emission of such solvent to the environment.

\section{ACKNOWLEDGEMENT}

The Authors express their sincere gratitude to Ms. Deepa Verma, Director, Forensic Science Laboratory GNCT of Delhi and Shri K.C. Varshney, Head of Office, Regional Forensic Science Laboratory, Chanakyapuri New Delhi for their keen interest and encouragement. The authors are particularly grateful to Mr. Srinarain, Head of Office,
Forensic Science Laboratory GNCT of Delhi. Ms. Anusha Srivastava, Intern, Department of Chemistry, Banaras Hindu University, UP is acknowledged for literature survey.

\section{ETHICAL ISSUES \\ None}

\section{CONFLICTS OF INTEREST}

There are no financial, or other, reasons that could lead to a conflict of interest.

\section{AUTHOR CONTRIBUTIONS}

PC: carried the literature review, instrumental analysis, analysed data and participated in drafting the manuscript; KLV: conceptualizing, designing, supervising and interpreting the data pertaining to this case report; RC: performed experiments, instrumental analysis and analysed data; LTV: performed experiments, instrumental analysis and analysed data.

\section{REFERENCES}

1. Goel A. Violence\& protective measures for women development \& empowerment. Deep \& Deep publication, 2004: pp;3-4. ISBN-13: 978-8176294973

2. Kalaiyarasi R. Violence against women in India. Journal of Humanities \& Social Science. 2015: 20(2); 51-55.

3. Singh AK, Choudhary J. Violence against women \& children-Issues \&concerns. Serials Publications PVT. LTD., New Delhi, 2012; pp-1-2. ISBN 13: 9788183875257

4. Nagindrappa M, Radhika M.K. Women exploitation in Indian modern society. International Journal of Scientific \& Research Publication, 2013:3(2); 1-11 ISSN 2250-3153.

5. Verma KL, Rachna, Sharma M, Sarin RK, Kumar A. Investigating crime against woman- Can forensic scientist bridge the gap? Journal of Forensic Legal \& Investigative Sciences 2016:2, 011.DOI:10.24966/ FLIS-733X/100011

6. National Crime Record Bureau, India: Crime in India (2018), https://ncrb.gov.in/sites/default/files/Crime\% 20in\%20India\%202018\%20-\%20Volume\%201.pdf

7. Arora J. An empirical investigation of the crime against woman in India. The Rights, 2017: 3(1), ISSN: 2454-9096.

8. Uttar Pradesh tops in crime against women, says NCRB report. https://www.thehindu.com/news/ national/uttar-pradesh-tops-in-crimes-againstwomen/article30526919.ece accessed on 28 March 2020.

9. Nirbhaya Gang Rape: A Case study. https://blog.ipleaders.in/nirbhaya-gang-rape-casestudy/ accessed on 11 March 2020.

10. Murthy O.P., Reddy K.S. N. The Essentials of Forensic Medicine and Toxicology. $34^{\text {th }}$ Edition, Jaypee Brothers Medical Publishers2017. ISBN-13: 9789352701032 
11. Shakti Mills gangrape: State takes care of high profile survivors, ignores the poor https://www.firstpost. com/living/shakti-mills-gangrape-state-treated-twodifferent-victims-1627605.html accessed on 11 April 2020.

12. 23 year old woman kidnapped, gang raped in moving car for two hours in Faridabad. https://www. hindustantimes.com/delhi-news/23-year-oldwoman-kidnapped-gang-raped-in-moving-car-infaridabad/story-7P0ORiywUtgfvGBgcJPeul.html, accessed on 15 March 2020.

13. Haryana gang rape victim murdered. https://www .thehindu.com/news/national/other-states/haryanagang-rape-victim-murdered/article18448354.ece accessed on 15 March 2020

14. https://timesofindia.indiatimes.com/city/delhi/8month-old-girl-raped-by-28-yr-old-man-on-lifesupport/articleshow/62701606.cms accessed on 15 March 2020

15. Delhi student, 15 , hangs self. Parents say 2 teachers sexually harassed her. https://www.ndtv.com/indianews/class-9-student-allegedly-commits-suicide-innoida-family-blames-school-1826551 accessed on 21 March 2020.

16. A day after rape, Assam girl dies. https://timesofindia.indiatimes.com/city/guwahati/a ssam-two-minors-man-gang-rape-class-v-girl-set-heron-fire/articleshow/63440909.cms accessed 25 March 2020.

17. Stalked by neighbor, 17 year-old police aspirant commits suicide. https://timesofindia.indiatimes. com/city/delhi/stalked-by-neighbour-17-year-oldpolice-aspirant-commits-suicide/articleshow/ 63448249.cms accessed on 25 March 2020.

18. A 21 yrs. old held for raping minor cousin. https://timesofindia.indiatimes.com/topic/21-yearold-held-for-raping-minor accessed 29 March 2020.

19. Woman hangs self, alleges harassment. https://timesofindia.indiatimes.com/city/hyderabad/ hyderabad-woman-hangs-self-due-to-alleged-dowryharassment/articleshow/71873918.cms accessed 2 April 2020.

20. Delhi bus rapist blames his victim in prison interview.https://www.telegraph.co.uk/news/worldn ews/asia/india/11443462/Delhi-bus-rapist-blameshis-victim-in-prison-interview.html. accessed on 29 March 2020.

21. Unnao Rape Case: A Timeline https://www.indiatoday.in/india/story/unnao-rapecase-a-timeline-1576186-2019-08-01 accessed on 2 April 2020
22. Telangana Doctor rape-murder: Chilling developments that sent shockwaves across countryhttps://www.indiatoday.in/india/story/telang ana-doctor-rape-murder-chilling-developments-thatsent-shockwaves-across-country-1623810-2019-1129.in accessed on 2 April 2020

23. Facts and figures: Ending violence against women. https://www.unwomen.org/en/what-we-do/endingviolence-against-women/facts-and-figures accessed on 4 April 2020

24. Man accused of using chloroform, acetone on teen step daughter. https://www.kiro7.com/ news/local/ man-accused-of-using-chloroform-acetone-on-teenstepdaughter/1011111642/ accessed on 4 April 2020.

25. Jamshedpur Women attempts suicide near CM's residence, hospitalized https://www.avenue mail.in/jamshedpur/jamshedpur-woman-attemptssuicide-near-cms-residence-hospitalized/121507/ accessed on 4 April 2020.

26. Girl drinks phenyl protesting insult by BDU teacher. https://timesofindia.indiatimes.com/city/trichy/girldrinks-phenyl-protesting-insult-by-bduteacher/articleshow/72078899.cms accessed on 6 April 2020.

27. India Court Conviction Rate 2000-2018 yearly \% National Crime Records Bureau, https://www. ceicdata.com/en/india/crime-statistics/courtconviction-rate accessed on 20 April 2020

28. Rao MS. Toxicology Manual, Directorate of Forensic Science, Ministry of Home Affairs, Government of India, New Delhi, First Edition,2005; Selective and Scientific Books.

29. Martz W. A lethal Ingestion of a Household Cleaner Containing Pine Oil and Isopropanol. Journal of Analytical Toxicology.2010; 34:49-52.

30. Yu Huang, Steven Sai Hang Ho, Kin Fai Ho, Shun Cheng Lee, Yuan Gao, Yan Cheng, C.S. Chan. Characterization of Biogenic Volatile Organic Compounds (BVOCs) in Cleaning Reagents and Air Fresheners in Hong Kong. Atmospheric Environment. 20011;45: 6191-6196.

31. Manjhi SN, Buktar SB, Mukherjee BB, Farooqui JM. Suicidal Death Due to Floor Cleaning Material: A Case Report. Pravara Med Rev. 2015; 7(1): 25-28.

32. Loza R and Rodriguez D. A Case of Methanol Poisoning in a Child. Case Reports in Nephrology.2014; Article ID 652129 | https://doi.org/ 10.1155/2014/652129.

33. Payne J.P. The Criminal Use of Chloroform. Anaesthesia.1998; 53:685-690. 
TABLES \& FIGURES

Table 1: Results of Case 1 and Case 2

\begin{tabular}{|c|c|c|c|c|c|c|}
\hline Case No. & $\begin{array}{l}\text { Name of } \\
\text { detected } \\
\text { compound }\end{array}$ & IUPAC name & $\begin{array}{l}\text { Retention } \\
\text { time (GC) } \\
\text { Min }\end{array}$ & $\begin{array}{l}\text { Peak detected } \\
\text { in } \mathrm{MS}(\mathrm{m} / \mathrm{z} \\
\text { ratio) }\end{array}$ & Conc. & LOD/LOQ \\
\hline \multirow{13}{*}{$\begin{array}{l}\text { Case } 1 \\
\text { (Yellow } \\
\text { colored } \\
\text { turbid } \\
\text { liquid) }\end{array}$} & alpha-pinene & $\begin{array}{l}\text { 4,6,6-trimethylbicyclo } \\
\text { [3.1.1] hept-3-ene }\end{array}$ & 11.613 & $\begin{array}{l}\text { 91.1, 92.1, 77, } \\
79.1, \& 121.1\end{array}$ & - & - \\
\hline & 3-carene & $\begin{array}{l}\text { 4,7,7-trimethylbicyclo } \\
\text { [4.1.0] hept-3-ene }\end{array}$ & 12.47 & $\begin{array}{l}93.1,77,121.1 \\
136.1, \& 105.1\end{array}$ & - & - \\
\hline & o-cymene & $\begin{array}{l}\text { 1-methyl-2-propan-2- } \\
\text { ylbenzene }\end{array}$ & 12.609 & $\begin{array}{l}119,134.1,91 \& \\
77\end{array}$ & - & - \\
\hline & D-limonene & $\begin{array}{l}\text { 1-methyl-4-(1- } \\
\text { methylethenyl)- } \\
\text { cyclohexene }\end{array}$ & 12.665 & $\begin{array}{l}93.1,68.1,79.1 \\
\& 121.1\end{array}$ & - & - \\
\hline & Eucalyptol & $\begin{array}{l}\text { 2,2,4-trimethyl-3- } \\
\text { oxabicyclo [2.2.2] octane }\end{array}$ & 12.717 & $\begin{array}{l}93.1,43,81.1 \& \\
108.1\end{array}$ & - & - \\
\hline & $\begin{array}{l}\text { gamma- } \\
\text { terpinene }\end{array}$ & $\begin{array}{l}\text { 1-methyl-4-propan-2- } \\
\text { ylcyclohexa-1,4-diene }\end{array}$ & 12.908 & $\begin{array}{l}93,91,77,136.1 \\
\& 121.1\end{array}$ & - & - \\
\hline & Ethyl Alcohol & Ethanol & 3.954 & & - & - \\
\hline & Toluene & Methylbenzene & 8.871 & & - & - \\
\hline & P-xylene & 1,4-Dimethylbenzene & 10.696 & & - & - \\
\hline & Fenchone & $\begin{array}{l}\text { 1,3,3- } \\
\text { Trimethylbicyclo(2.2.1)hept } \\
\text { ane-2-one }\end{array}$ & 13.243 & $\begin{array}{l}81,69,41 \& \\
152.1\end{array}$ & - & - \\
\hline & Fenchol & $\begin{array}{l}\text { (1R,2R 4S)-1,3,3-Trimethyl- } \\
\text { 2-norbornanol }\end{array}$ & 13.504 & $\begin{array}{l}81.1,69,41 \& \\
93\end{array}$ & - & - \\
\hline & Camphene & $\begin{array}{l}\text { 2,2-Dimethyl-3- } \\
\text { methylidenebicyclo(2.2.1) } \\
\text { heptane }\end{array}$ & 11.826 & $\begin{array}{l}93,121.1,107.1 \\
79 \& 67\end{array}$ & - & - \\
\hline & Isoborneol & $\begin{array}{l}(1 \mathrm{R}, 2 \mathrm{R}, 4 \mathrm{R})-1,7,7- \\
\text { Trimethylbicyclo(2.2.1)hept } \\
\text { ane-2-ol }\end{array}$ & 13.899 & $\begin{array}{l}95,93,41,67 \& \\
121.1\end{array}$ & - & - \\
\hline \multirow{3}{*}{$\begin{array}{l}\text { Case } 2 \\
\text { Transparent } \\
\text { liquid }\end{array}$} & $\begin{array}{l}\text { Methyl } \\
\text { Alcohol }\end{array}$ & Methanol & 3.7 & $31,32,29$ & $40 \mathrm{mg} / \mathrm{dl}$ & $\begin{array}{l}1.58 \mathrm{mg} / \mathrm{dl} \\
5.2 \mathrm{mg} / \mathrm{dl}\end{array}$ \\
\hline & Acetone & Propan-2-one & 4.1 & $43,58,42, \& 39$ & - & - \\
\hline & Ethyl Alcohol & Ethanol & 3.9 & 31,45 & - & $\begin{array}{l}0.79 \mathrm{mg} / \mathrm{dl} \\
2.6 \mathrm{mg} / \mathrm{dl}\end{array}$ \\
\hline
\end{tabular}
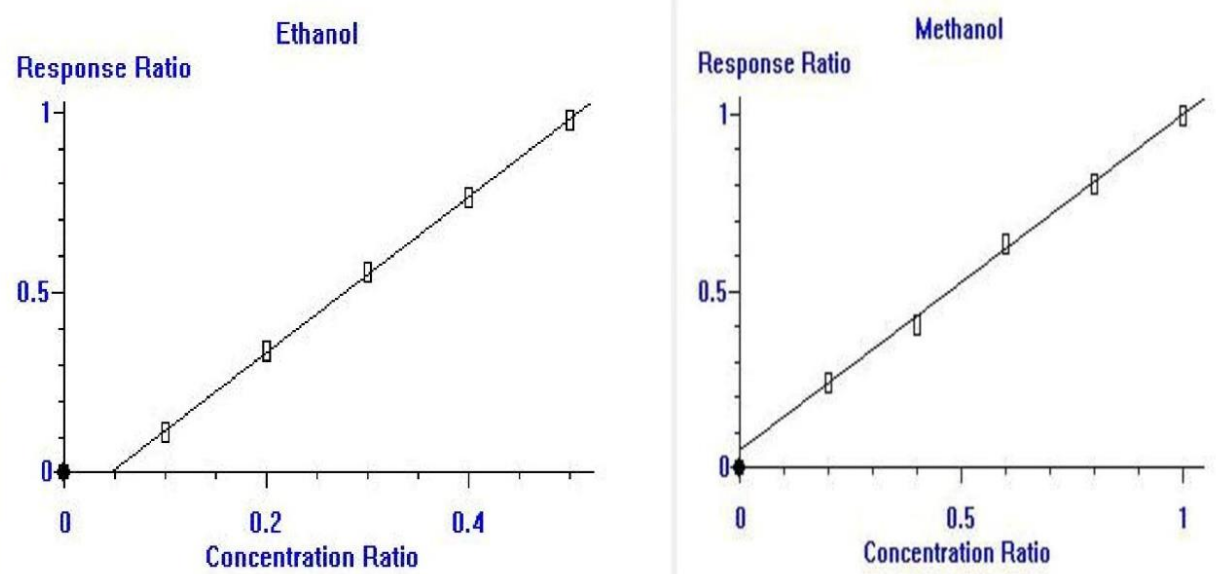

Fig. 1: Calibration curve for Methanol and Ethanol 


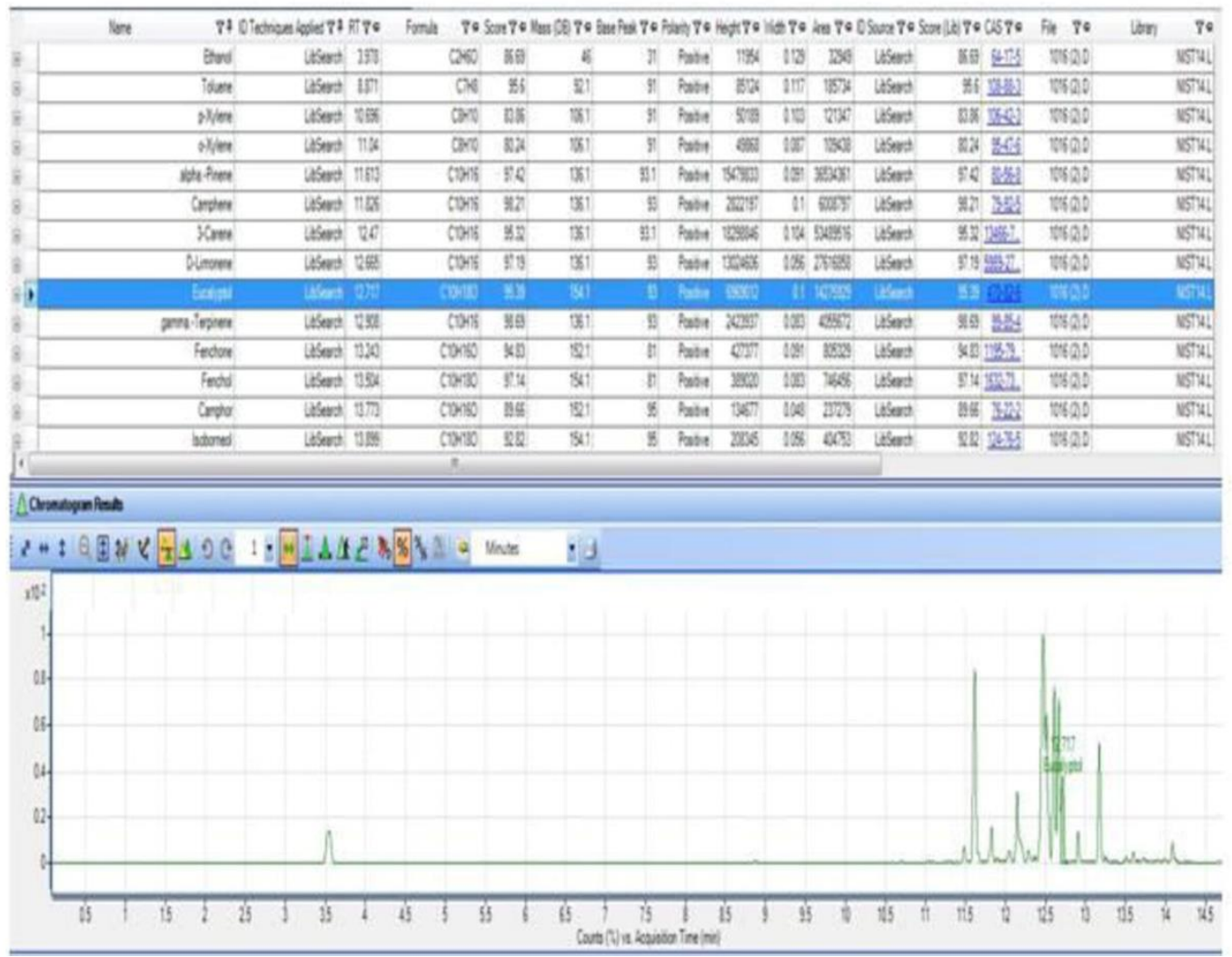

Fig. 2A: Gas Chromatogram (GC-MS) with compounds list of exhibits of case-1

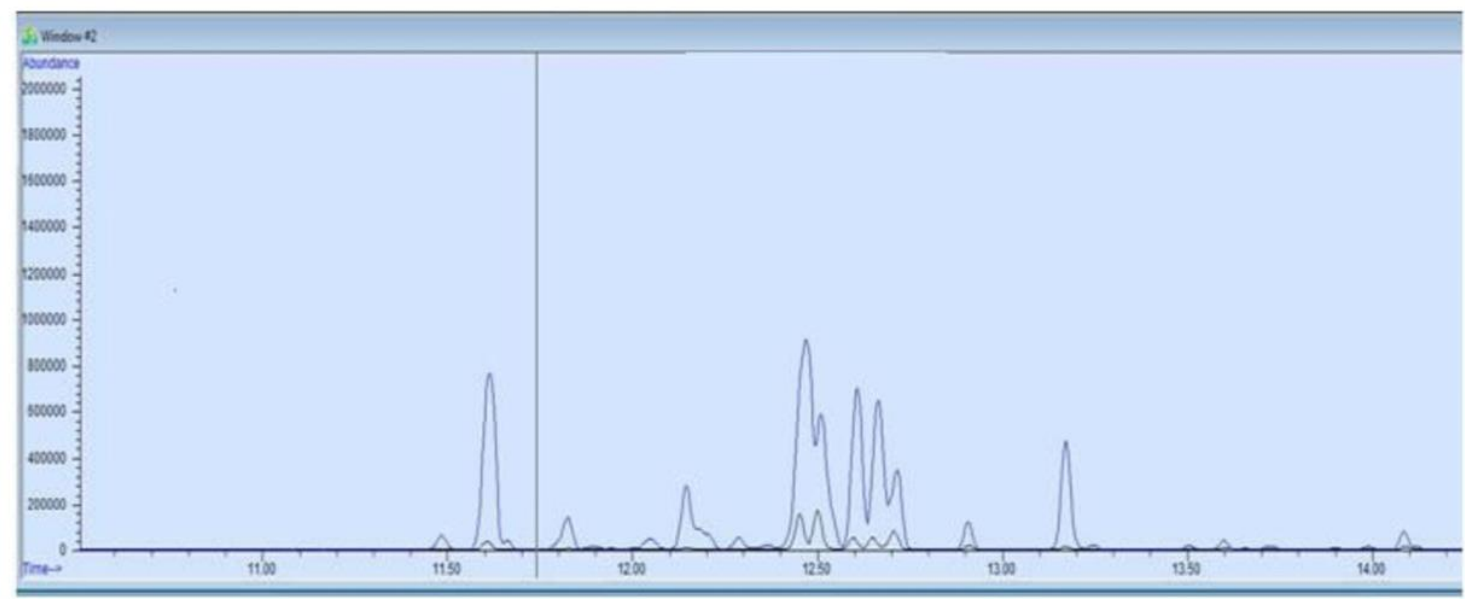

Fig. 2B: Overlay chromatogram (GC-HS-MS) of exhibit 1 and 2 of case-1 

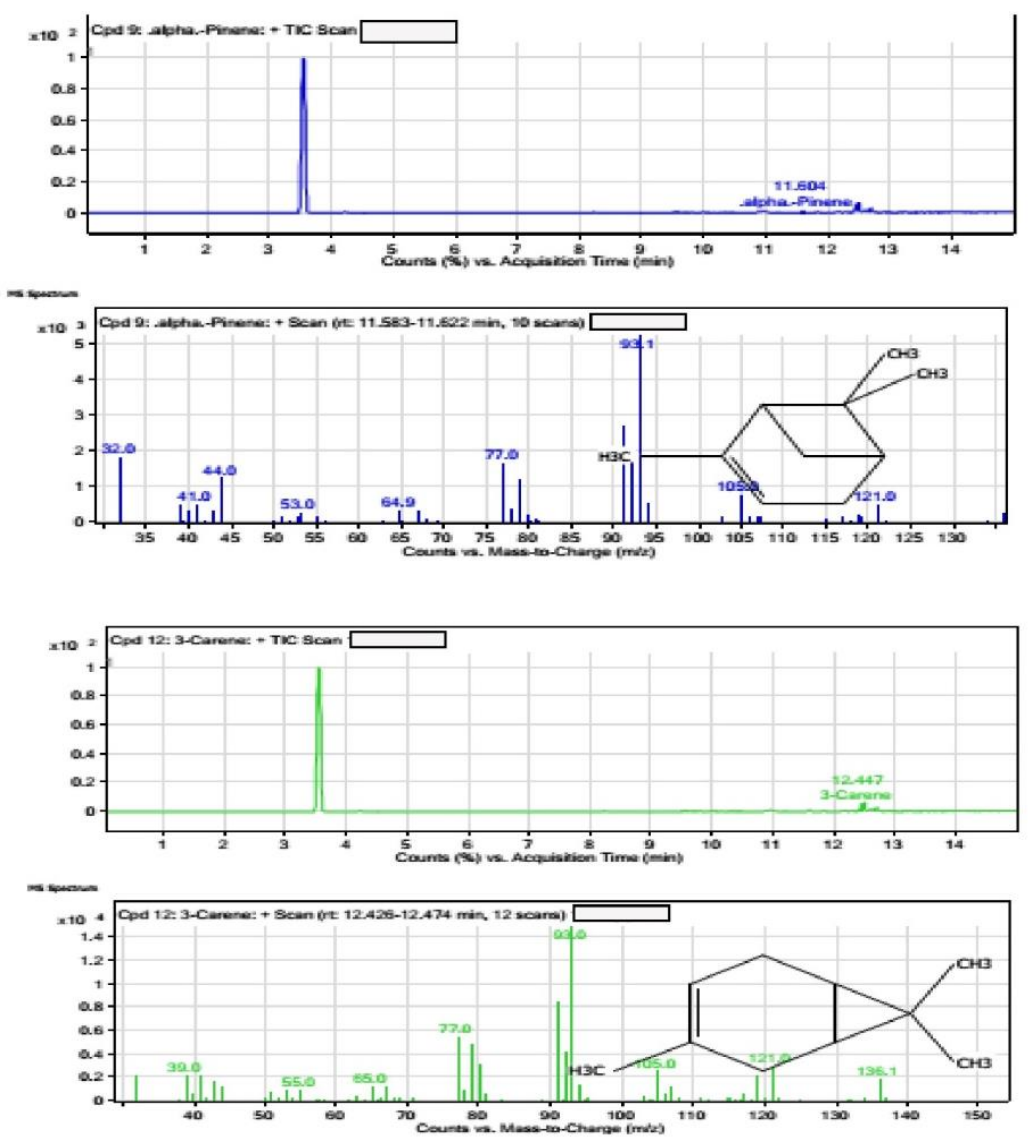

Fig. 2C: Gas-chromatogram (GC-HS-MS) of exhibit of case-1

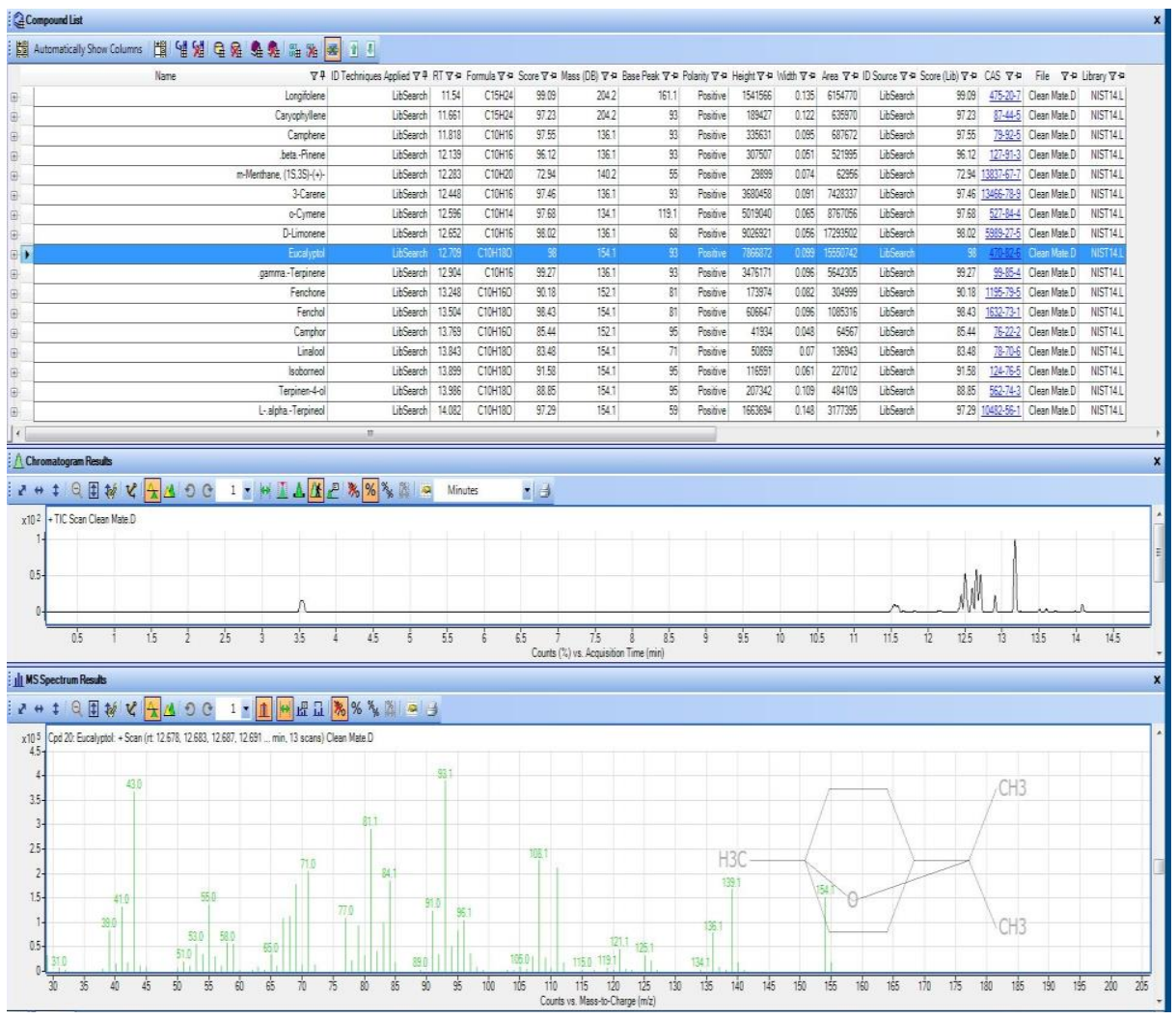

Fig. 2 D: Gas -chromatogram of Standard purchased from local 


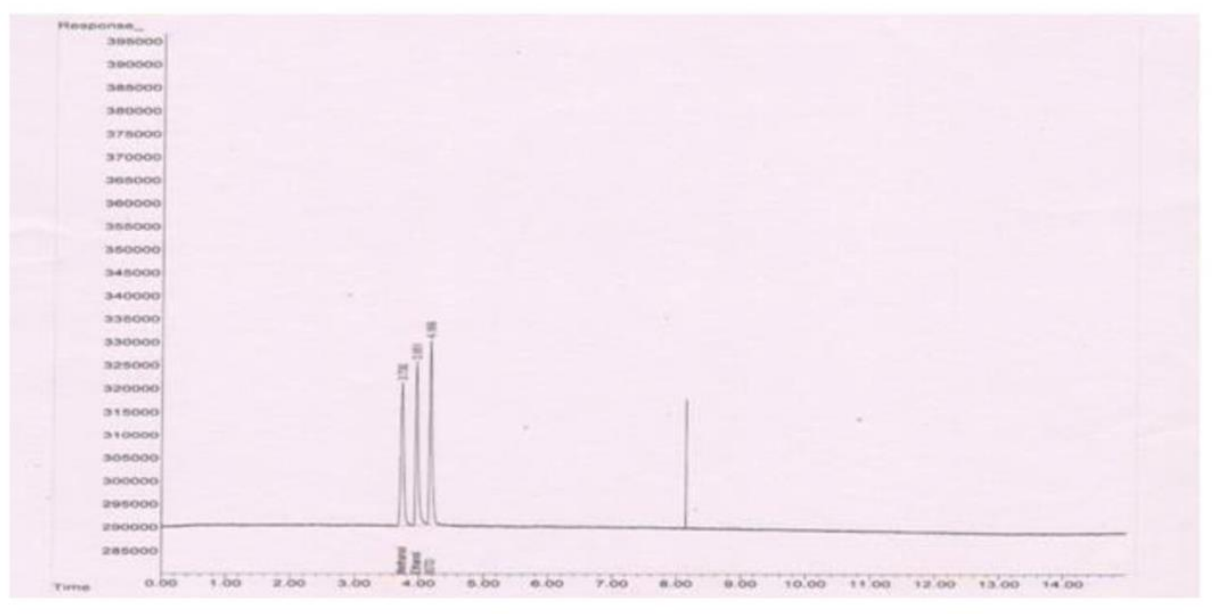

Fig. 3A: FID signals for methanol and ethanol and internal standard in case-2

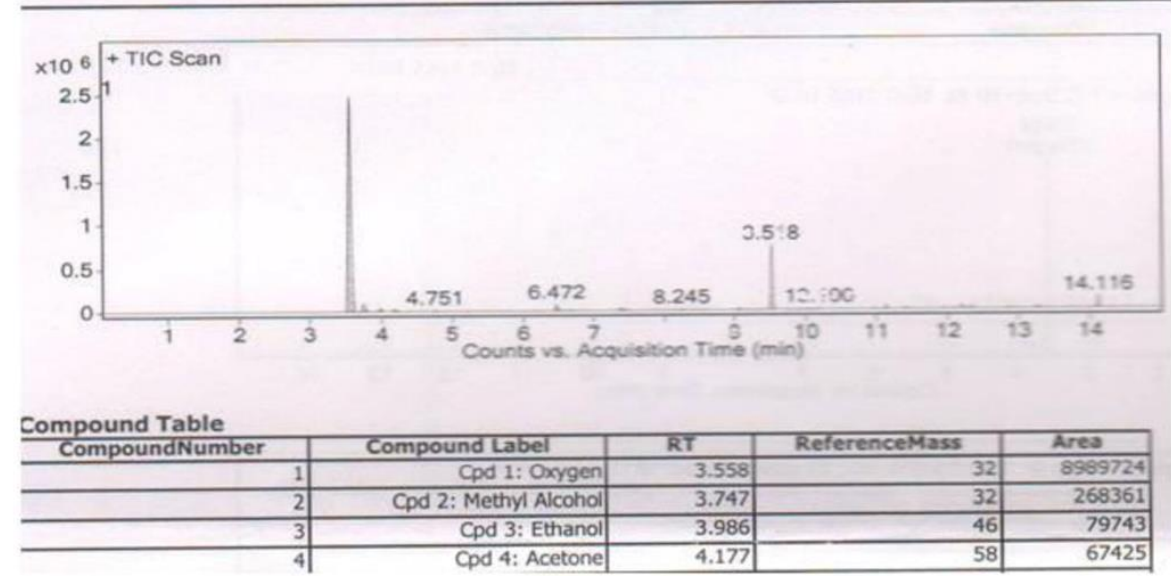

Fig. 3B: Gas chromatogram (GC-HS-MS) with compounds list of exhibit of case -2 